\title{
Provenance study of Permian non-marine sandstones and conglomerates of the Krkonoše Piedmont Basin (Czech Republic): exotic marine limestone pebbles, heavy minerals and garnet composition
}

\author{
KAREL MARTíNEK \& KATEŘINA ŠTOLFOVÁ
}

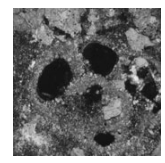

\begin{abstract}
This study focuses on identifying major source areas in several stratigraphic intervals in the Permian sediments of the Krkonoše Piedmont Basin and integrates it with existing sedimentological data. Pebbles in Cisuralian-Guadalupian conglomerates of alluvial fans, nearshore lacustrine and lacustrine fan-delta deposits that were deposited close to the northwestern and southeastern basin margin, respectively, correspond almost exclusively to local material from adjacent crystalline complexes. The heavy mineral associations of the sandstone matrix of these conglomerates support this interpretation. Crystalline units of the south-western part of the Krkonoše-Jizera Crystalline Complex and Orlice-Sněžník Crystalline Complex, respectively, are considered as the most favourable sources. Heavy mineral associations of fluvial sandstone facies are of complex composition pointing to repeated recycling of clastic material. However, heavy mineral indices reveal distinct source areas for the main lithostratigraphic units. Two main possible source areas for the fluvial Asselian deposits (Vrchlabí Formation) of the south-western part of the basin were found. Pebbles of late Devonian-early Carboniferous marine limestones probably came from the central part of the hypothetical Jitrava-Hradec Basin. The garnet compositions in sand detrital material point to leucogranites and pegmatites of the north-eastern Moldanubian Zone, Přibyslavice area, as the possible source rocks. Guadalupian fluvial deposits reveal a wide range of sources that can be attributed to the recycling of detrital material from Cisuralian and Carboniferous deposits. Garnet compositions indicate Moldanubian granulites, garnet clinopyroxenites, leucogranites and pegmatites as a possible sources. We infer that Moldanubian granulites and garnet clinopyroxenites were exposed to an erosion level in the Early Permian at the latest. $\bullet$ Key words: provenance, Krkonoše Piedmont Basin, Permian, heavy minerals, pebble composition, detrital garnet composition.
\end{abstract}

MARTÍNEK, K. \& ŠTOLFOVÁ, K. 2009. Provenance study of Permian non-marine sandstones and conglomerates of the Krkonoše Piedmont Basin (Czech Republic): exotic marine limestone pebbles, heavy minerals and garnet composition. Bulletin of Geosciences 84(3), 555-568 (8 figures, 2 tables). Czech Geological Survey, Prague. ISSN 1214-1119. Manuscript received May 15, 2006; accepted in revised form January 26, 2009; published online August 13, 2009; issued September 11, 2009.

Karel Martinek, Institute of Geology and Palaeontology, Charles University, Albertov 6, 12843 Prague 2, Czech Republic; karel@natur.cuni.cz • Kateřina Štolfová, School of Geological Sciences, University College Dublin, Belfield, Dublin 4, Ireland

Conglomerate pebble composition can be a good indicator of adjacent source areas in basin studies, but it usually does not provide information on more distant sources of detrital material. A heavy mineral association (HMA) from sandstones and a sandstone conglomerate matrix can indicate more distant sources. In areas with complex source rock lithologies (igneous, low-grade and/or medium-grade metamorphics, volcanics), the HMA can often contain mixed provenance information that is not easy to interpret. An effective method for discriminating the specific source areas could be integrating palaeocurrent data with a detailed mineral chemistry determination using an electron microprobe (e.g.,
Morton 1985, Owen 1987, Morton 1991). Garnets with a potentially wide range in composition show significant differences in composition among different types of garnet-bearing lithologies (Čopjaková et al. 2005). Another advantage of garnet for provenance studies is its relative stability during diagenesis (Morton \& Hallsworth 1999).

The aims of this study include determining the source areas of the Vrchlabí and Trutnov formations of the Krkonoše Piedmont Basin based on pebble composition, heavy mineral assemblages, and detrital garnet compositions. Additionally, previously acquired palaeocurrent data obtained by conventional sedimentological methods are integrated. 


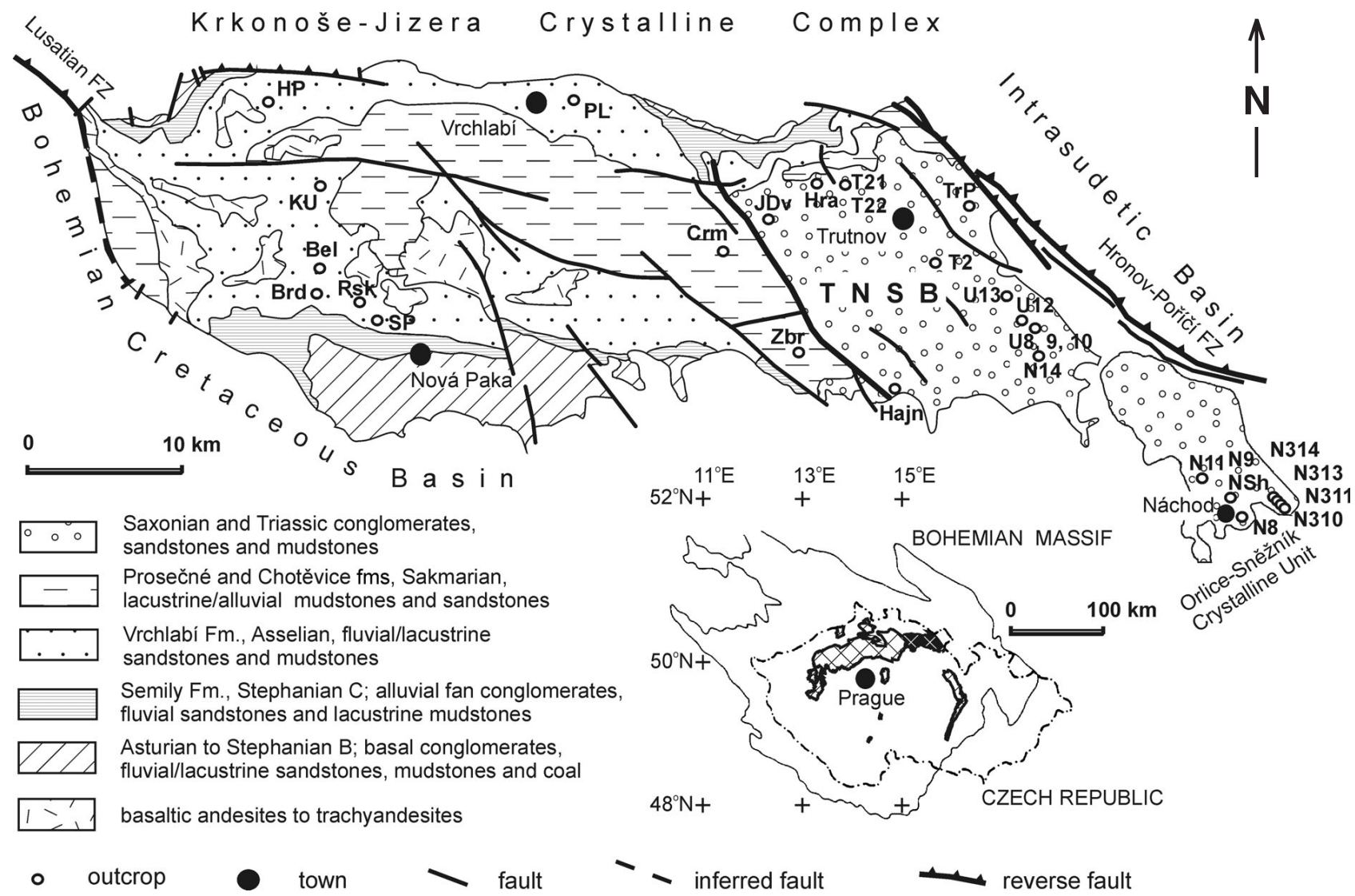

Figure 1. Simplified geological map of the Krkonoše Piedmont Basin (KPB) with sample locations. Inset map: outline of non-marine Permo-Carboniferous basins (hash) and KPB (black hash). Outcrop samples: Bel - Bělá, Brd - Brodky, Crm - Čermná, Haj - Hajnice, HP - Honkův potok, Hra - Hrádeček, JDv - Janský Dvůr, KU - Kundratice, N9, NSh, N8 - Náchod, N11 - Dolní Radechová, N310, N311, N313, N314 - Náchod-Běloves, N14 - Havlovice, PL - Prostřední Lánov, Rsk - Roškopov, SP - Stará Paka Railway Station, T21 and T22 - Pekelský vrch, TrP - Trutnov-Pořičí, T2 - Trutnov - Starý Rokytník, U13 - Suchovršice, U8, 9, 10, 12 - Úpice, Zbr - Záboří.

The composition of detrital garnets from fluvial Early Triassic deposits of Bohdašín Formation is also discussed.

\section{Geological setting}

The Krkonoše Piedmont Basin formed as part of a system of extensional/transtensional, intermontane basins during the post-Variscan period (Asturian-Triassic, Fig. 1). There has been systematic geological research on the Late Carboniferous-Triassic basin fill during the last several decades. This research was mainly based on geological mapping and several structural boreholes were also made. The lithostratigraphic concept of the basin was established by Tásler $e t$ al. (1981), Tásler \& Prouza (1985), and a summary of this research was presented by Prouza \& Tásler (2001). The provenance of selected sedimentary units was determined by Prouza \& Tásler (2001) based mainly on the pebble composition of conglomerates. They suggest the following sources of the clastic material:

1. for the Stará Paka Sandstone (Vrchlabí Formation): material eroded from the underlying Semily Formation (the presence of cherts and tuffs of Ploužnice Stephanian C age, cropping out in the western part of the basin);

2. Horní Město Member (Trutnov Formation): material transported from the north (the pebbles composed almost entirely of Krkonoše-Jizera Crystalline Complex rocks crystalline limestone (dominant, up to 90\%), quartzite, lydite, gneiss, mica shist, granitoid; Upper Palaeozoic volcanites and sediments are rare);

3. for the Náchod Conglomerates (Trutnov Formation): material transported from the south (based on the presence of pebbles of Orlice-Sněžník Crystalline Complex - phyllite, granite, granite porphyry, crystalline limestone, quartzite).

Pebble composition provides basic information on the provenance of local, coarse-grained, shortly transported material and did not allow distant source areas to be determined. Novák et al. (1983) analysed heavy minerals of the Vrchlabí Formation from ZŽ-1 borehole. They found a poor HMA that varied little with a predominance of zircon, tourmaline, monazite and with sporadic occurrence of 
magnetite, apatite, garnets and Cr spinel, assuming lowgrade metamorphic and acid igneous source rocks. Sedimentological research has been conducted recently (Blecha et al. 1999, Martínek 2003, Martínek et al. 2006), but palaeocurrent analysis gives only limited information on provenance, because of the limited amount of suitable outcrops, and the difficulties in correlating important outcrops. Basin-wide unconformities (Fig. 2) and changes in the thicknesses of sedimentary units indicate substantial shifting of depocentres at the Stephanian B/C (mid Gzhelian) and Autunian/Saxonian (Lower/Upper Rotliegende, Cisuralian/Guadalupian) boundaries that led to changes in basin configuration. The depocentres were shifting from the south to the north at the Stephanian B/C boundary, which was noted, e.g., by Pešek $(1994,2005)$ as a common feature in Central and Western Bohemian Carboniferous-Permian sedimentary basins. The shift in depocentre location was interpreted as a switching of the major displacement from southern to northern marginal faults still in an extensional half-graben setting (Uličný et al. 2002, Martínek et al. 2006). At the Cisuralian/Guadalupian boundary a major tectonic rearrangement of the basin occurred, probably from an extensional to a strike-slip regime (Uličný et al. 2002).

Palaeocurrent analysis of the fluvial sandstones of the Vrchlabí Formation (Asselian) at the south-western part of the Krkonoše Piedmont Basin reveals dominant NNE trending palaeocurrent vectors (Štolfová 2004). Fluvial sandstones of the Trutnov Formation (Guadalupian), deposited after major unconformity in the eastern part of the basin, show a low spread of palaeocurrent vectors trending to the north and northeast (Martínek 2003). Very similar north-eastern trends of fluvial sandstones of the Trutnov Formation were observed in the adjoining south-western part of the Intrasudetic Basin (Lojka 2003). This is in agreement with Prouza \& Tásler (2001) who suggested a single depositional area covering the eastern part of the Krkonoše Piedmont Basin (Trutnov-Náchod Subbasin) and Intrasudetic Basin during the Guadalupian.

\section{Methods}

The individual methods used in provenance studies have different significance and are influenced by a number of factors that complicate the recognition of provenance. Therefore a complex approach integrated the modal composition of sandstones and the typology of quartz grains of sandstones (23 samples from Vrchlabí Formation, 42 samples from Trutnov Formation), pebble composition data ( 15 beds of 5 outcrops from the Vrchlabí Formation, 9 beds of 8 outcrops from the Trutnov Formation were inspected), heavy mineral analysis (67 samples), and garnet composition (5 rock samples, which correspond to 43 grains and 150 spot analyses).

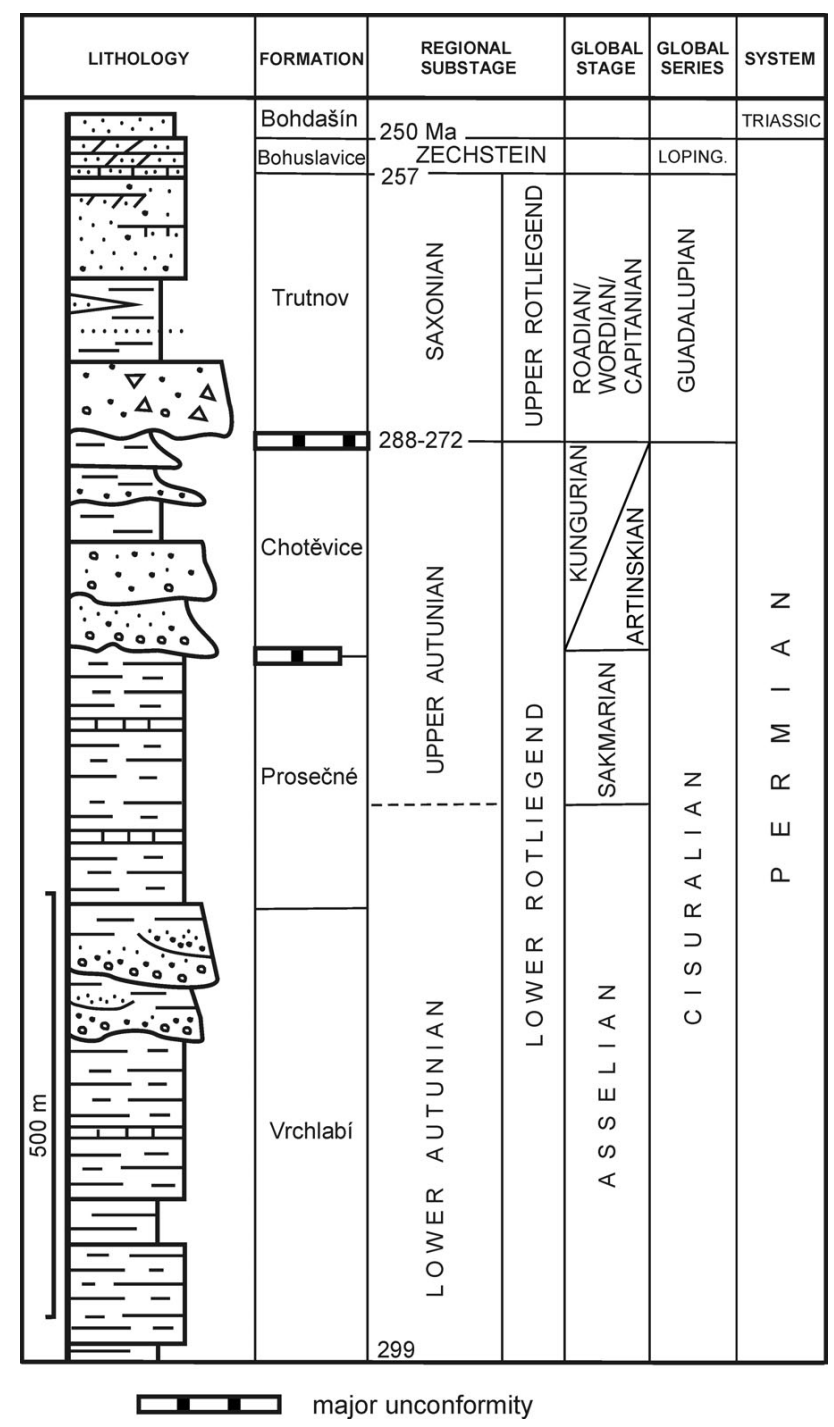

Figure 2. Stratigraphical chart of the Permian and Triassic of the Krkonoše Piedmont Basin based on the borehole Pé-1 in the centre of the basin (Asselian-Cisuralian) and on the compiled stratigraphy of the Trutnov-Náchod Subbasin (Guadalupian-Triassic, Prouza \& Tásler 2001). Time values in Ma from Haq (2007).

Modal composition was studied using standard petrological optical microscopy with semiquantitative estimates of each component. Pebble composition was determined at outcrops using lithology identification of all pebbles in 1 square meter of vertical outcrop section of each bed. Heavy mineral assemblages provide the main database that was further processed to separate provenance-specific features and to eliminate other factors. The main sample set was taken from outcrops of the Vrchlabí and Trutnov formations, and several samples were also taken from the surrounding units. Sample location is indicated in Fig. 1, sample age in Table 1 (see electronic Appendix A). Heavy mineral samples were processed by the laboratories of the Czech Geological Survey, Prague. Heavy minerals were 
separated from the sand fraction sieved below $0.5 \mathrm{~mm}$ (70 g samples) using heavy liquids (tetrabromethane $\mathrm{C}_{2} \mathrm{H}_{2} \mathrm{Br}_{4}, 2.95 \mathrm{~g} / \mathrm{cm}^{3}$ ) from disintegrated, washed and dried sandstone samples (2-5 kg field specimens). Individual minerals were identified using a standard petrologic optical microscope; X-ray diffraction and electron microprobe analyses were carried out where necessary for proper mineral identification. The chemical composition of garnet was determined by electron microanalysis. Analyses were carried out at the Laboratory of Electron Microscopy and Microanalysis (Charles University in Prague) using a CamScan S4 scanning electron microscope with an energy dispersive analytical system Oxford instruments LINK ISIS 300. The beam current was $7 \mathrm{nA}$. Accelerating voltage was $20 \mathrm{kV}$. Acquisition time was 170 seconds. The energy resolution of the EDS spectra was $72 \mathrm{eV}$. The analysis was corrected by using the conventional ZAF correction method $(\mathrm{Z}=$ atomic number factor, $\mathrm{A}=$ absorption factor, $\mathrm{F}=$ characteristic fluorescence correction) to quantify the spectra. $\mathrm{Mg}, \mathrm{Al}, \mathrm{Si}, \mathrm{Ca}, \mathrm{Ti}, \mathrm{Cr}, \mathrm{Mn}, \mathrm{Fe}$ and $\mathrm{V}$ were analysed with following detection limits: $\mathrm{MgO}(0.21 \mathrm{wt} . \%)$, $\mathrm{Al}_{2} \mathrm{O}_{3} \quad\left(0.19\right.$ wt.\%), $\mathrm{SiO}_{2} \quad(0.18$ wt. $\%), \quad \mathrm{CaO} \quad(0.10$ wt.\%), $\mathrm{TiO}_{2}$ (0.08 wt.\%), $\mathrm{V}_{2} \mathrm{O}_{5}(0.13 \%), \mathrm{Cr}_{2} \mathrm{O}_{3}(0.08$ wt. \%), $\mathrm{MnO}$ (0.08 wt.\%), FeO (0.13 wt.\%). The SPI Supplies 53 Minerals Standard Set \#02753-AB was used for routine quantitative calibration.

\section{Results}

\section{Modal and pebble composition}

The study was focused mainly on the pebble and modal composition of the Vrchlabí Formation fluvial deposits, where exotic limestone pebbles were found and where information on the source areas was scarce. The source areas are expected south of the basin, according to palaeocurrents (Štolfová 2004), and are mostly covered by Late Cretaceous deposits.

The provenance analysis of fluvial deposits of the Vrchlabí Formation is based on the modal composition of sandstones, the pebble composition of conglomerates and the typology of the quartz grains. Identification of rock composition is based on a hand specimen and a thin section study. Conglomerates are oligomictic to polymictic in nature with pebble and cobble sizes ranging from 0.5 to $16 \mathrm{~cm}$. Pebbles of quartzite, para- and orthogneiss, lydites and acid volcanics are common. Clasts of metamorphic rocks are well rounded, generally better than the other pebbles. Sandstones are mainly composed of quartz grains (58-82 vol.\%) with variable rounding and levels of preservation. The grains are sub-angular to sub-oval and commonly replaced by calcite cement. Quartz grains are interpreted in terms of four possible origins: plutonic, low-grade metamophic, high-grade metamorphic and volcanic (Basu et al. 1975). Plagioclase and K-feldspar usually range from 2 to 12 vol.\%. The individual samples show low variability in feldspar content. Carbonate cement and plutonic quartz are found in all samples, the original mud-rich matrix is rarely preserved. The presence of biotite, which breaks down easily due to its mechanical and chemical instability, points to a very close source area, possibly the adjacent Zvičina Crystalline Unit (adjacent to basin margin south-east of Nová Paka). Metamorphic rock fragments, mostly altered phyllites, quartzitic phyllites and quartzites, are probably derived from underlying Carboniferous deposits; they are very similar to material from the Krkonoše-Jizera and Zvičina crystalline complexes (Kachlík 2004, pers. comm.). Acid volcanic rock fragments probably have their origin in the southern part of the Krkonoše Piedmont Basin.

In the outcrops of the Stará Paka Railway Station locality, five pebbles of shallow marine limestone were found in fluvial sandstones. These pebbles occur in several beds and their size ranges from 3 to $5 \mathrm{~cm}$ in diameter. They contain abundant bioclasts, both intact and fragmented, of open marine and shallow water carbonate origin. The rich faunal assemblage includes foraminifers, ostracods, brachiopods, molluscs, sponge spicules and less abundant crinoids, echinoderms and calcispheres (Fig. 3). Limestone is highly recrystallized, originally probably biomicritic. Interestingly, some of the elongated bioclasts, which are interpreted as algae, are silicified and infilled by bitumen.

The preserved benthic foraminifers in these marine limestone pebbles have a more complex test shape than those known from Early and Middle Devonian strata (Poiarkov 1969). However, the test shapes are not as complex as those typical for fusulinids of the Late Carboniferous and Permian times (Tappan \& Loeblich 1988; Kalvoda 1990, 2002). Hence we conclude that the foraminifers probably fall within the Late Devonian (late Famennian) to Early Carboniferous (Tournaisian-Viséan) age interval. Other abundant fossils such as ostracods, brachiopods, molluscs and calcispheres are difficult to identify precisely, because of the diagenetic overprint of the limestones, mainly neomorphism, and are therefore poor indicators of exact limestone age. The identification of algae remnants, with solid bitumen inclusions and the occurrence of spheroidal or oval fossils, which have a thick outer wall, remain problematic. The diverse assemblage of organisms and their abundance points to a normal salinity environment. The occurrence of the benthic foraminifers and other organisms listed above suggests an open marine shelf or epicontinental sea environment in a tropical or subtropical climate.

Modal and pebble composition of other samples of the Trutnov Formation point to local crystalline rock sources that are known from previous works (summarized in 

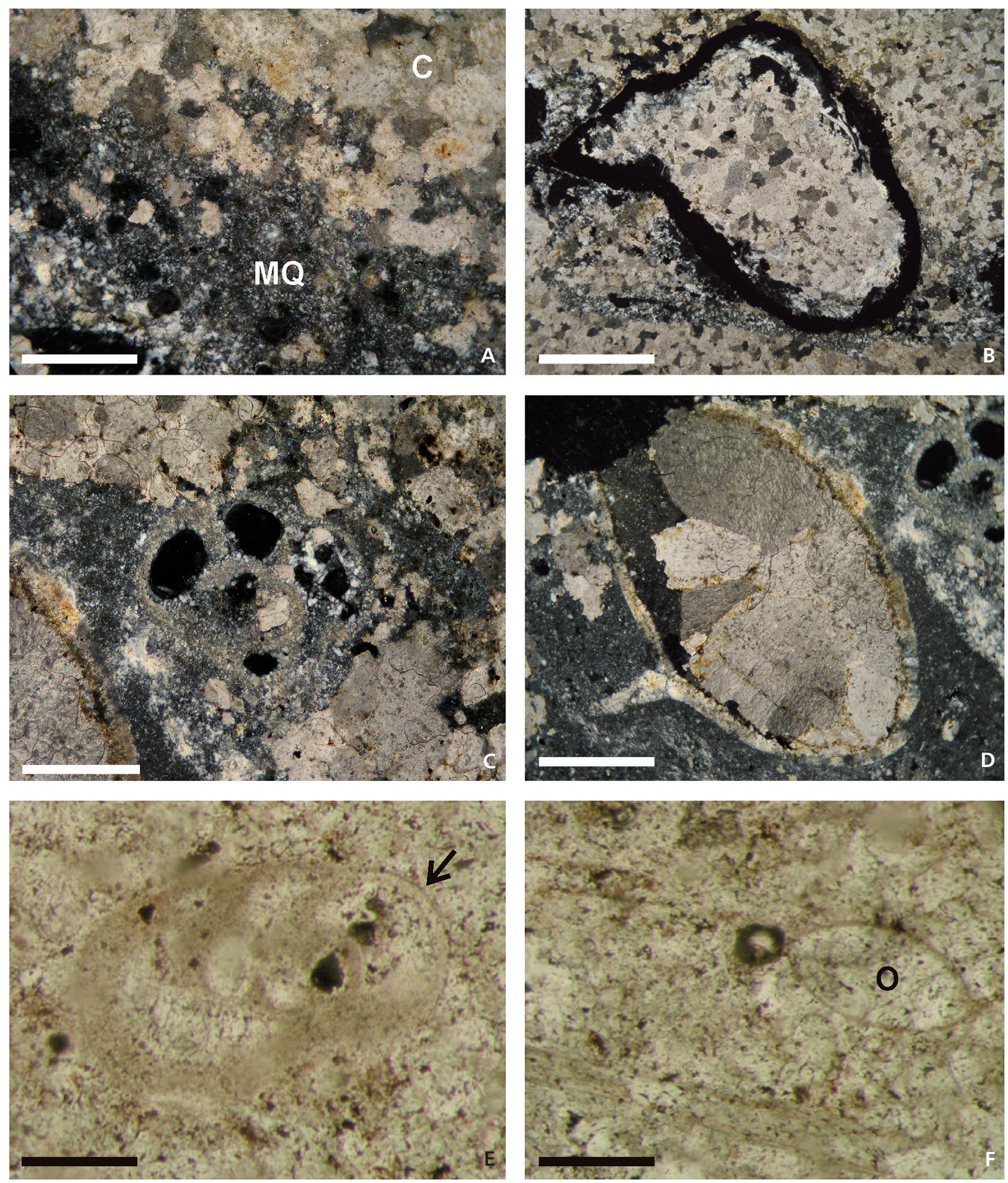

Figure 3. Photomicrographs of limestone pebbles from the Vrchlabí Formation, locality Stará Paka Railway Station. • A - limestone silicification. Microquartz (MQ) replacing calcite spar (C). Crossed nicols, scale bar $0.5 \mathrm{~mm}$. $\bullet$ B - bioclast or intraclast is surrounded by organic matter (black). Crossed nicols, scale bar $0.2 \mathrm{~mm}$. $\bullet \mathrm{C}$ - the foraminifers have more cells than foraminifers of Lower and Middle Devonian age. They have more complicated forms that are more typical of foraminifers from the Carboniferous or uppermost Devonian. Crossed nicols, scale bar $0.4 \mathrm{~mm}$. $\bullet \mathrm{D}-\mathrm{the}$ shell of a mollusc or brachiopod is filled by calcite spar, whereas foraminifer is partly silicified (top right). Crossed nicols, scale bar $0.5 \mathrm{~mm}$. $\bullet \mathrm{E}-\mathrm{a}$ photomicrograph showing details of another foraminifer, at its right side the shell wall is well preserved (arrow). Parallel nicols, scale bar $0.8 \mathrm{~mm}$. $\bullet \mathrm{F}-\mathrm{ostracod}$ shell (O) and elongated fragments of unknown origin (algae?). Parallel nicols, scale bar $1.2 \mathrm{~mm}$. 
Prouza \& Tásler 2001). Therefore these results are not presented or discussed in this study.

\section{Heavy mineral suite}

Heavy minerals are subject to a varying rate of alteration and disintegration during weathering in the source area, transport to the basin, weathering during periods of alluvial storage on the floodplain, diagenesis during burial, and weathering at the outcrop of sedimentary rock. These processes significantly affect the proportions of individual heavy minerals found in the sedimentary record, which can differ from the proportions of accessory minerals in the source area. Haughton et al. (1991), Morton \& Hallsworth (1994, 1999) discussed the factors influencing heavy mineral composition and Morton \& Hallsworth (1994, 1999) isolated provenance-sensitive features, and avoided parameters that are influenced by other factors. The mineral indices proposed by these authors can eliminate transport/weathering/diagenetic modifications. Such an approach is successful in identifying provenance. The results obtained are summarized in Fig. 4, where detrital heavy minerals are plotted.

The major components of the heavy mineral association found in most samples are zircon, apatite, tourmaline and garnet. These minerals could originate from a wide range of possible source rocks: metamorphic, plutonic, volcanic, either from the adjacent Krkonoše-Jizera Crystalline Complex or many other source rocks south of the basin. Cretaceous marine sedimentary rocks cover some potential source areas south of the studied basin, which are therefore not accessible for direct study. The provenance-specific minerals presented in Fig. 4 are not abundant in all samples. For example, in conglomerates deposited close to the basin margin (Náchod and Horní Město conglomerates) rock fragments (quartzite, phyllite, highly altered - Fe-oxidized - phyllite) and Fe oxides predominate in the heavy fraction. The interpretation of the relative proportions of the individual heavy minerals in the samples, where the sum of these selected provenance-specific minerals is less than $5-10 \%$ of the total HMA, must be done very carefully. There may be significant errors in calculating the relative proportions of minerals. Several distinct HMA, which are also supported by distinct heavy mineral (HM) indices, were found (Fig. 5). Stephanian C samples from the north-western part of the basin have an association of monazite-tourmaline-gahnite that is similar to Cisuralian samples from the north-western and north-central parts of the basin, while Cisuralian samples from the south-western part of the basin (near Stará Paka, samples SPxyz, Fig. 5A) have a different association dominated by pyroxene-ilmenite-rutile-tourmaline-garnet. Sakmarian samples Crm and Zbr belong to the Prosečné
Formation, they have a very simple mineral association dominated by tourmaline. The lower part of Guadalupian deposits is characterised by an ilmenite-rutile-tourmaline association, while Upper Guadalupian deposits have an ilmenite-rutile-tourmaline-garnet association. Kyanite and staurolite were also found sporadically. They occur in the fluvial sandstones of the Trutnov and Vrchlabí formations.

The RuZi $\left(100 \times \mathrm{TiO}_{2}\right.$ group $/ \mathrm{TiO}_{2}$ group + zircon $), \mathrm{GZi}$ $(100 \times$ garnet/garnet + zircon $)$ and ATi $(100 \times$ apatite/apatite + tourmaline) HM indices of Morton \& Hallsworth (1999) give other provenance specific information. On the GZi/ATi plot (Fig. 5) the distinct composition for the Horní Město and Náchod conglomerates, the Čistá Sandstone, the upper part of the Havlovice Sandstone, the Prosečné Formation and the last group with similar heavy mineral composition including Kumburk and Semily formations (Pennsylvanian), Stará Paka Sandstone, Rudník Member, and the lower part of Havlovice Sandstone were recognized.

\section{Garnet composition}

An effective method for discriminating specific source areas is detailed mineral chemistry determination using an electron microprobe (Morton 1985, Owen 1987, Morton 1991). Garnet composition was successfully used for the provenance study of clastic material of the Early Carboniferous foreland Culm Basin deposits of the Moravo-Silesian Zone at the eastern margin of the Bohemian Massif (Čopjaková et al. 2005). The results of garnet electron microprobe analyses from the Krkonoše Piedmont Basin (Permian-Triassic) are summarized in Figs 6, 7, selection of representative analyses are presented also in Table 2 (see electronic Appendix B). Garnet separation was carried out on 15 samples representing the main stratigraphic units. Unfortunately, many samples contain garnet grains of small size, and they are highly weathered. Only 5 samples contained garnet grains of size and preservation suitable for electron microprobe analysis. They included one sample of Asselian and Triassic, respectively, and three samples of Guadalupian age.

Sample SPU-1 (Fig. 7, one grain was analysed) comes from the fluvial sandstones of the Vrchlabí Formation, Asselian, the Stará Paka railway station locality, the same locality from which Devonian/Carboniferous marine limestone pebbles were described. Dominant spessartine (0.7) composition with very low almandine $(0.15)$, grossular (0.05) and pyrope (0.01) components. The absence of zonality is characteristic.

Samples U13 (Figs 6 and 7, six grains were analysed) are from the upper part of the fluvial sandstone unit of the Trutnov Formation (Guadalupian, locality Suchovršice Adamov near Úpice), Unit 3B sensu Martínek (2003). Most garnet grains are dominated by almandine $(0.45-0.65)$, have high pyrope (0.25-0.45), low grossular (less than 0.1 ) and 


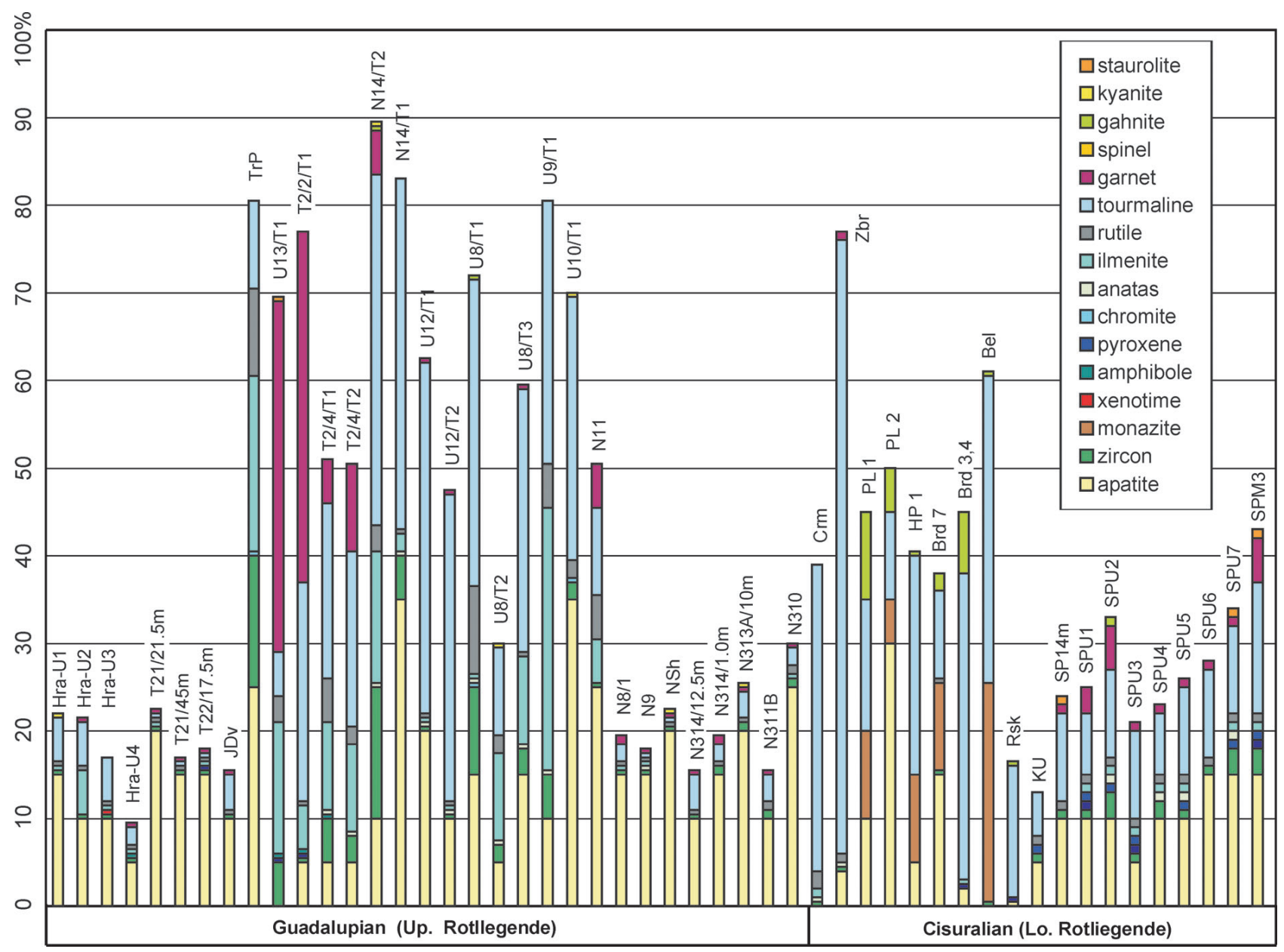

Figure 4. Detrital heavy minerals. Only heavy minerals considered as primary and derived from source rocks are presented. Rock fragments, carbonates, muscovite, biotite/phlogopite and diagenetic and other secondary minerals are not included. Carboniferous rocks represent sandstones and a sandstone matrix of conglomerates; sampled crystalline rocks include low grade metamorphics.

very low spessartine components (less than 0.05). Zonality is absent. Anomalous very high almandine (0.70) and low pyrope (0.09) grain (U13-T1-2); and very high xMg garnet also occurs (U13-T1-4, up to 0.50 pyrope).

Samples T2-3-T1 (Figs 6 and 7, 13 grains analysed) are from fluvial sandstones of the Trutnov Formation (Trutnov-Starý Rokytník, Unit 3B). Most grains (8) are of almandine (0.65-0.8) - pyrope (0.25-0.05) composition with variable grossular $(0.05-01)$ and spessartine (0.15-less than 0.05). Two spessartine (0.4-0.45) - almandine (0.35-0.38) dominated grains have a grossular component of $0.1-0.2$. Three grains are pyrope $(0.6-0.38)-$ almandine (0.1-0.38) dominated with grossular of $0.15-0.25$, one of these grains (T2-3-T1-45) has 0.6 pyrope and 0.1 uvarovite (Cr garnet). Garnets T2-3-T1-06 and T2-3-39 have a prograde chemical zonality preserved with a high $\mathrm{xMg}$ value in the rim (0.35-0.45 pyrope, 0.3-0.6 almandine, $0.2-0.1$ grossular).

Sample T21-21-1 (Fig. 7, one grain was analysed) comes from the Horní Město Conglomerates of the Trutnov Forma- tion, alluvial fan deposits forming a narrow (up to $1 \mathrm{~km}$ ) fringe along the northern margin of the Trutnov-Náchod Subbasin (north of Vlčice and Trutnov). Conglomerate pebbles are composed of local material from the Krkonoše-Jizera Crystalline Complex (Prouza \& Tásler 2001), but the garnet sample is from a sandstone matrix, which can contain material from more distal sources. In addition, a major unconformity at the base of the Trutnov Formation was accompanied by significant tectonic rearrangement of the basin (Uličný et al. 2002) that caused uplift and erosion of older strata. Clasts of Stephanian C age within the Trutnov Formation are reported by Prouza \& Tásler (2001). A dominant almandine (0.6)-spessartine (0.2) composition with low $\mathrm{xMg}, \mathrm{Ca}$ and the absence of zonality was found.

In samples Hajn (Figs 6 and 7, locality Hajnice, Bohdašín Formation, Early Triassic, fluvial red bed "Buntsandstein" facies, 22 grains) almandine (0.7-0.55)-pyrope (0.2-0.45) garnets with variable grossular $(0.05-0.15)$ and very low spessartine (less than 0.05$)$ prevail (14 grains). Five grains are almandine (0.6-0.8) dominated with a low 


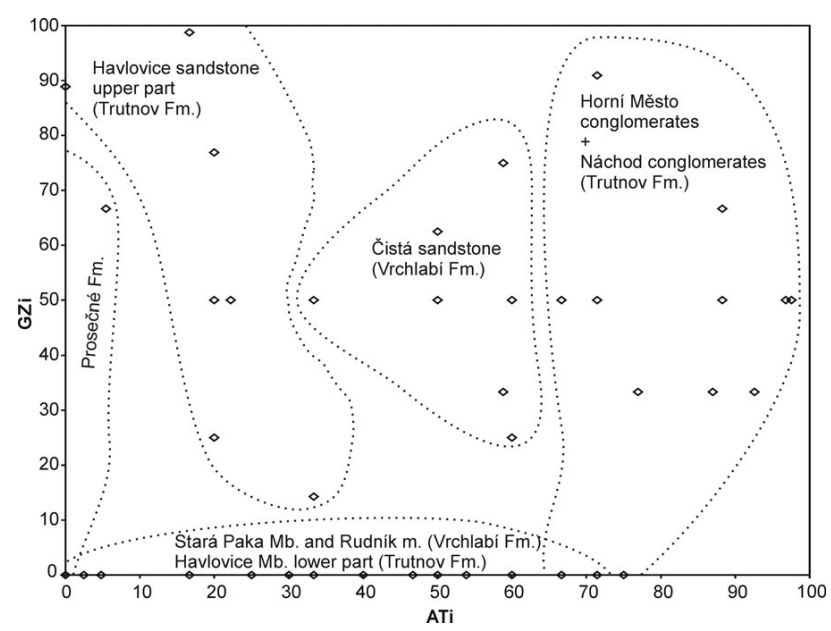

Figure 5. The heavy mineral indices of Morton \& Hallsworth (1999) point to distinct source rocks of individual lithostratigraphical units.

grossular (0.05-0.1) and variable spessartine (0-0.2) component. Two grains are pyrope $(0.42-0.45)$ dominated with almandine (0.35-0.38), grossular (0.21-0.23) and very low spessartine (less than 0.05). Most pyrope-almandines have flat profiles. In garnets Hajn3 and Hajn23 a weak prograde zonality can be observed. There is a slight increase in $\mathrm{xMg}$ from the core to the rim (see Figs 7, 8). Only grain Hajn 18 has a higher pyrope $(0.45)$ component $(0.35$ almandine, 0.2 grossular).

Although there is a wide variety in garnet composition among the studied samples, some could be grouped according to similarities in composition. The high $\mathrm{xMg}$ garnet of U13-T1-4 (up to 0.50 pyrope) is similar to T2-3-T1-37, T2-3-T1-39 and Hajn18 (pyrope 0.45, almandine 0.35 , grossular 0.2). Almandine-pyrope garnets of T2-3-T1 (0.65-0.45 almandine, $0.45-0.25$ pyrope) have a composition similar to sample U13. A dominant almandine (0.6)-spessartine (0.2) composition with high $\mathrm{Mn}$ and low $\mathrm{xMg}, \mathrm{Ca}$ and the absence of zonality is characteristic for the samples T21-21-1, T2-3-T1-32 and SPU-1.

\section{Discussion}

Based on the provenance-specific clastic materials found in the samples studied, we discuss possible source areas for particular stratigraphic units. Where direct evidence is missing, we comment on the possibility of other source areas. The conglomerates of alluvial fan deposits, which were deposited close to the basin margin, contain almost exclusively local material in the pebbles (e.g., Semily Formation near Semily; Lánov Conglomerates near Vrchlabí, Vrchlabí Formation; Horní Město Conglomerates near Trutnov, Trutnov Formation; Náchod Conglomerates near Náchod, Trutnov Formation). Our findings are consistent with the interpretations of Prouza \& Tásler (2001).

\section{Provenance of exotic limestone pebbles}

We describe, for the first time, the occurrence and composition of exotic marine limestone pebbles within the fluvial sandstones of the Vrchlabí Formation. Palaeocurrent data indicate a sediment supply from the south or southwest of the Krkonoše Piedmont Basin. As stated above the most likely age of this limestone is Upper Devonian or Lower Carboniferous. We consider the deposits of the JitravaHradec Basin (sensu Čech et al. 1989) to be the most likely source of pebbles. This hypothetical sedimentary basin is known only from relics in which marine deposits of Late Devonian and Early Carboniferous age occur. Deposits are preserved only in the Ještěd area (near Jítrava) and in several boreholes near Hradec Králové. Upper Devonian to Lower Carboniferous in situ marine limestone was encountered in the Nepasice borehole near Hradec Králové. Stromatoporoids, foraminifers and algae of probable Upper Famenian age (Zukalová 1976) were found in the limestone samples taken from the base of the carbonate sequence. A specimen of rugose coral was also found and its age is Late Famennian (Galle 1976). In the Nepasice borehole, the limestone sequence has some features in common with the development of the Ještěd area, but its appearance and fossil content is most similar to the Devonian of Moravia, namely the Moravian Karst facies (Chlupáč \& Zikmundová 1976). It can also be correlated to Dzikowiec in the Klodzko region, Poland (Gluszek \& Tomas 1994). The limestones of the Jitrava area are of Famennian age and contains a trilobite and conodont fauna. They are organic matter rich in places and may represent a mid to deeper shelf marine environment (Chlupáč 1964, 1997). Although the fossil content of the limestone pebbles from the Stará Paka Railway Station locality corresponds with neither the Nepasice nor the Jitrava occurrence (Kalvoda 2004, pers. comm.), the age of the deposits correspond well. The source of limestone pebbles could be in the central part of the Jitrava-Hradec Basin, where, unfortunately, the sedimentary record of this age is not known. This area is extensively covered by Pennsylvanian non-marine and Late Cretaceous marine deposits, but Devonian/Carboniferous deposits could have also been eroded during the Mississipian/Pennsylvanian tectonostratigraphic rearrangement of the area.

\section{Inferences from heavy minerals}

The stratigraphic significance of HMA and their usage for outcrop correlation within the Trutnov Formation is discussed elsewhere (Martínek 2003). This study is focused on the interpretation of possible source areas. The HM composition of most samples is highly complex and it is not easy to extract provenance-specific information from. 
Boundaries of the main lithostratigraphic units are marked with changes in HMA (Fig. 5A, B). The similarity in the association of monazite-tourmaline-gahnite in the Stephanian $\mathrm{C}$ samples from the north-western part of the basin and Cisuralian samples from north-western and northcentral parts of the basin point to the existence of a similar source area for this part of the basin during the Stephanian $\mathrm{C}$ and Cisuralian. Samples are mostly from basin margin clastics (alluvial fan, nearshore lacustrine, lacustrine fan-delta facies). Monazite is not very significant, but it is abundant in granitoids and orthogneisses. Gahnite was not described thus far from either the marbles or metapelites of the Krkonoše-Jizera Crystalline Complex, but some calc-silicate rocks of contact metamorphic zones are possible candidates; gahnite is known from the Staré Město Crystalline Complex and the Moldanubian Zone. Tourmaline is abundant in the phyllites and shists of the Krkonoše-Jizera and Zvičina crystalline complexes. Possible source areas include some units of the south-western part of the Krkonoše-Jizera Crystalline Complex or overlying units that have been eroded away.

Cisuralian samples from the south-western part of the basin have a different association dominated by pyroxeneilmenite-rutile-tourmaline-garnet. Samples come from fluvial facies of the Vrchlabí Formation, for which palaeocurrents indicate transport from the south. Source areas of the fluvial sandstones could be more distant. More information is needed to determine particular units of the central and southern Bohemian Massif as possible source areas (see discussion of garnet composition below). The simple mineral association (dominated by tourmaline) of the Sakmarian samples ( $\mathrm{Crm}$ and Zbr belonging to the Prosečné Formation) could be explained in terms of destruction of less stable heavy minerals. Unstable heavy minerals were probably disintegrated and weathered due to a prolonged exposure on the floodplain. The Prosečné Formation is characterised by a low-gradient alluvial-lacustrine system with low subsidence rates and a semi-arid climate (Martínek 1995, Prouza \& Tásler 2001), and long-time exposure of sediments on the floodplain is expected. The stratigraphy of garnet-free and garnet-rich units of the Guadalupian is discussed in Martínek (2003) in detail. It could be concluded that a major change in source areas is expected at the mid-Guadalupian basin-wide unconformity. Changes in HM composition of various stratigraphic units point to tectonic and tectonostratigraphic changes in source areas that correlate with tectonosedimentary changes within the basin. At least the Cisuralian/Guadalupian unconformity, but probably also Stephanian B/C and mid-Guadalupian unconformities, could be correlated with these changes. Minerals pointing to more distant sources are kyanite and staurolite. These minerals occur in the fluvial sandstones of the Trutnov and Vrchlabí formations that have palaeoflows directed to the north and northeast. Kyanite and staurolite do not occur in either the adjacent Krkonoše or Zvičina crystalline complexes. The closest occurrence of such minerals is in the Orlice-Sněžník granulites or Moldanubian metamorphics.

\section{Inferences from garnet composition}

Garnet SPU-1 with a dominant spessartine (0.7) composition with very low almandine $(0.15)$, grossular $(0.05)$ and pyrope (0.01) components and an absence of zonality is interpreted as probably coming from a magmatic source; garnets from leucocratic granites and pegmatites can have a similar composition. Mn rich garnets are described e.g., by Breiter (2005) from orthogneisses, pegmatites and granites near Prribyslavice, the NE part of the Moldanubian Zone (7-15 wt.\% MnO). Alternatively, very similar garnet (0.6 Sps, $0.15 \mathrm{Grs}, 0.15 \mathrm{Alm}$ ) with an absence of zoning also occurs in the blueschists of the eastern part of the Krkonoše-Jizera Crystalline Complex in Sněžný potok near Žacléř (Žáčková 2006 pers. comm.). Nevertheless, palaeocurrent data show an opposite direction, which eliminates this source from further discussion.

Most U13-T1 garnet grains are dominated by almandine (0.45-0.65), have high pyrope $(0.25-0.45)$ and very low spessartine and grossular components (less than 0.05). Such a composition and the absence of zonality (similar to sample Hajn) are interpreted as possibly indicating a granulite source. Tajčmanová et al. (2006) described garnets from felsic granulites of the Strážek Unit, NE Moldanubian Zone (approx. $90 \mathrm{~km} \mathrm{SE}$ of Krkonoše Piedmont Basin), of the eastern Bohemian Massif, with a similar composition (0.55-0.85 Alm, 0.1-0.3 Pyr, Spes and Grs less than 0.05) and an absence of zonality. Similar bright garnets, with a composition of 0.30-0.64 Alm, 0.14-0.40 Pyr, 0.05-0.27 Grs, were described by Fiala \& Kopecký (1964) from Carboniferous sandstones of the borehole Třtěno Tř-1 near Louny, the Kladno-Rakovník Basin, and interpreted by these authors as coming from felsic granulites. The garnets from the Křištanov Granulite of Farský Hill, southern Bohemian Moldanubian Zone (approx. 200 km south of Krkonoše Piedmont Basin) have a lower pyrope component (0.18-0.20 Pyr, 0.66-0.73 Alm, 0.1-0.02 Grs and 0.02 Sps, Verner 2006 pers. comm.), similar to samples U13-T1-3a and 3b. Anomalous very high $\mathrm{xMg}$ garnet also occurs here (U13-T1-4, up to 0.50 pyrope), its composition is similar to T2-3-T1-39 and Hajn18. They can come from Moldanubian garnet pyroxenites, as is, e.g., an occurrence in Bezděčín near Tábor (approx. $160 \mathrm{~km}$ south of the studied basin) has garnets with $0.44 \mathrm{Pyr}, 0.37$ Alm and 0.16 Grs (Machart \& Paděra 1982).

Most of the garnet grains of the sample T2-3-T1 are of dominant almandine-pyrope and pyrope-almandine composition. Those without zonality could be interpreted as 


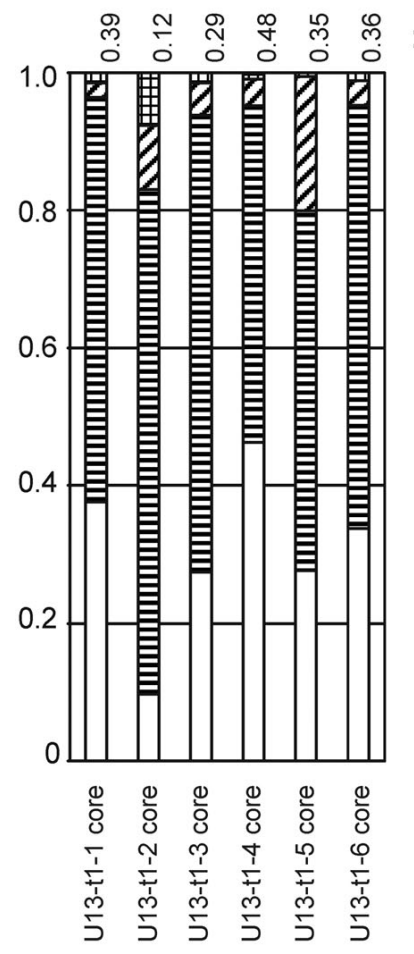

田 $\mathrm{Mn}_{3} \mathrm{Al}_{2} \mathrm{Si}_{3} \mathrm{O}_{12}$ (spessartine)

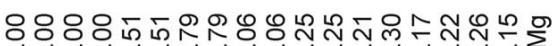

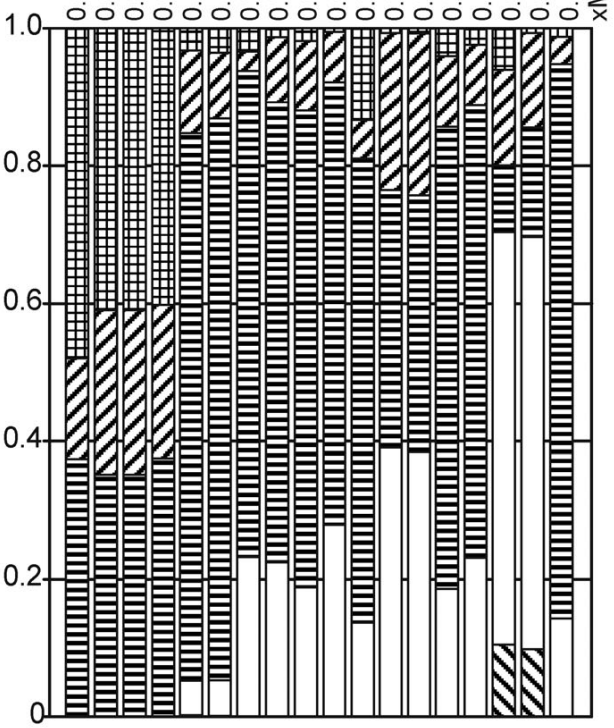

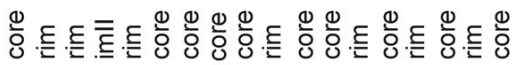

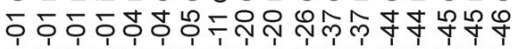
1 N

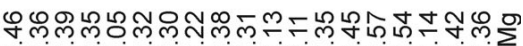

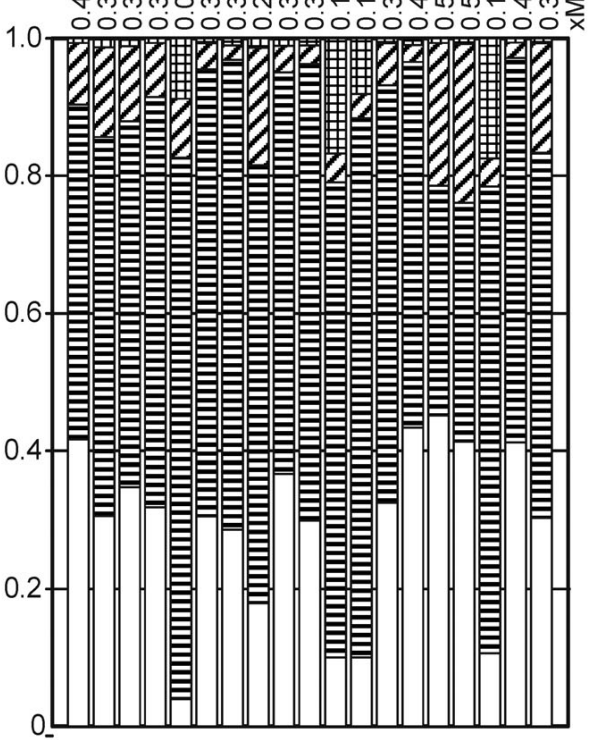

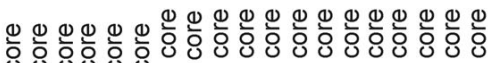

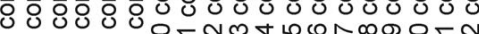
ษ.ำ

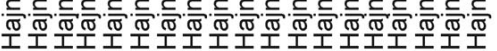

$\mathrm{Mg}_{3} \mathrm{Al}_{2} \mathrm{Si}_{3} \mathrm{O}_{12}$ (pyrope)

$$
\boldsymbol{\square} \mathrm{Ca}_{3} \mathrm{Al}_{2} \mathrm{Si}_{3} \mathrm{O}_{12} \text { (grossular) } \quad \boldsymbol{E} \mathrm{Fe}_{3} \mathrm{Al}_{2} \mathrm{Si}_{3} \mathrm{O}_{12} \text { (almandine) } \mathbf{\Delta}(\mathrm{Mg}, \mathrm{Fe}, \mathrm{Ca})_{3} \mathrm{Cr}_{2} \mathrm{Si}_{3} \mathrm{O}_{12}
$$

Figure 6. Garnet composition revealed from single point analyses of the grains in samples U13-T1, Úpice, Trutnov Formation, Early Permian (Upper Rotliegende); T2-3-T1, Trutnov - Starý Rokytník, Trutnov Formation; Hajn, Hajnice, Bohdašín Formation, Triassic.

coming from granulites south of the basin. Garnet T2-3-T1-06 has prograde chemical zonality preserved. A high $\mathrm{xMg}$ value in the rim points to a possible high-grade metamorphic source. The preservation of zonality can be interpreted as being due to lower $\mathrm{P} / \mathrm{T}$ conditions (amphibolite facies) or just a short exposure of the garnet at granulite facies conditions. Garnet T2-3-T1-39 has prograde zonality and a high pyrope component, but also a high almandine component. This composition is rare and can be compared with garnet clinopyroxenites that are associated with eclogites and ultramafic rocks in the Moldanubian Zone. The high Mn garnet T2-3-T1-32 with an absence of zonality is interpreted as possibly coming from a magmatic source, leucocratic granites and pegmatites can have a similar composition. The Cr-pyrope grain T2-3-T1-45 with 0.5-0.6 Pyr, 0.1-0.15 Alm, 0.1-0.15 Grs and a 0.1 uvarovite component has an affinity to violet $\mathrm{Cr}$-pyropes from Podsedice (near Lovosice, western Bohemia, 0.75 Pyr, 0.12 Alm, 0.09-0.12 Uvr, Sps and Grs less than 0.01 ) that originate in pyrope lherzolite on peridotite bodies in basement gneisses and which have been recycled several times to Permo-Carboniferous, late Cretaceous and Pleistocene deposits and Neogene volcanic breccia (Seifert
\& Vrána 2005). The composition of particular grains in this sample is rather variable pointing to source areas south, southeast and southwest of the basin. These areas are not necessarily considered as primary sources of detritic material. Several phases of recycling of older sedimentary units (Carboniferous, Cisuralian) is expected at the major intervals of the basin tectonic rearrangements indicated, e.g., by basin-wide unconformities (Stephanian B/C, Cisuralian/Guadalupian).

Garnet T21-21-1 has a dominant almandine (0.6) spessartine (0.2) composition with high $\mathrm{Mn}$, low xMg, Ca and the absence of zonality, interpreted as possibly coming from a magmatic source, leucocratic granites, orthogneisses and migmatites. The sample is similar to garnets T2-3-T1-26, U13-T1-2 and Hajn14, but the sample comes from a sandstone matrix of Horní Město Conglomerates and is located close to the northern margin of the basin. The pebbles originated from the Krkonoše-Jizera Crystalline Complex but the sandstone matrix may contain material recycled from older strata (Carboniferous, Cisuralian).

Most Hajn garnets are almandine rich and have flat profiles. In garnets 3 and 23 a weak prograde zonality can be observed. There is a slight increase in $\mathrm{xMg}$ from the 
SPU1-1

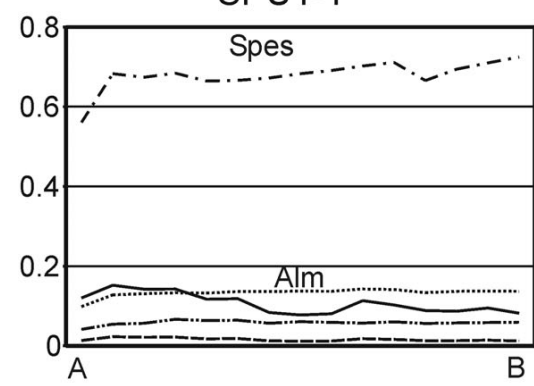

T2-3-T1-06

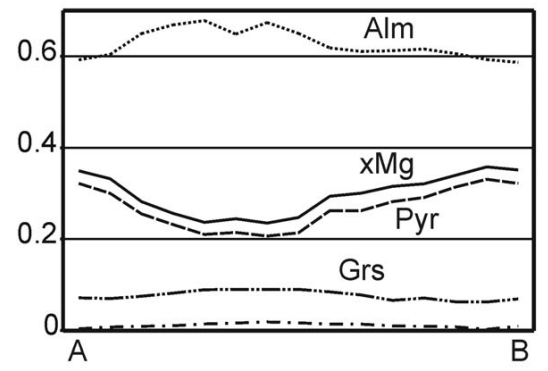

T21-21-1

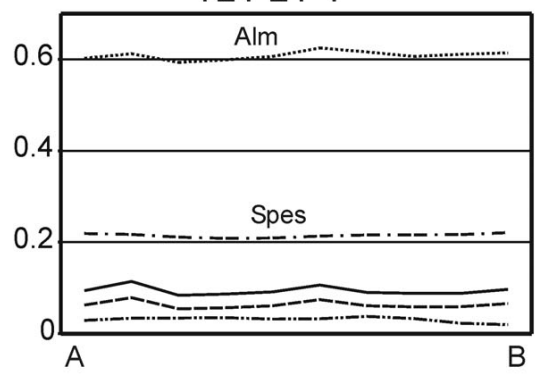

Hajn6

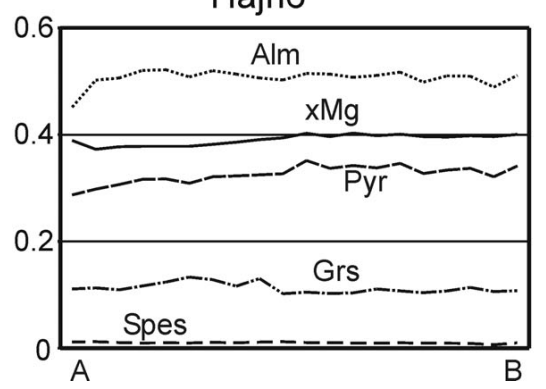

U13-T1-1

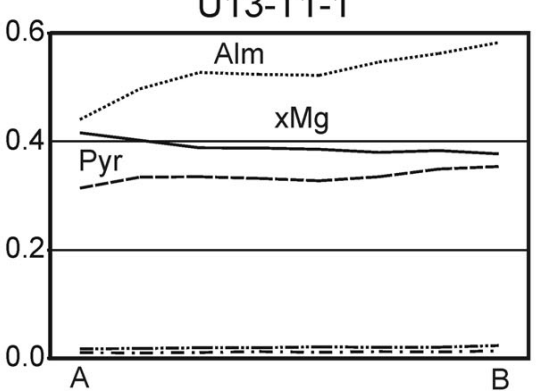

T2-3-T1-32

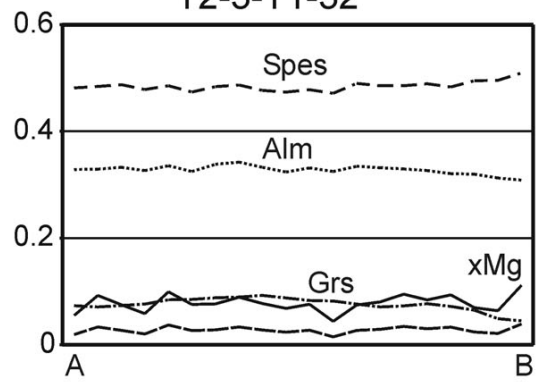

Hajn2

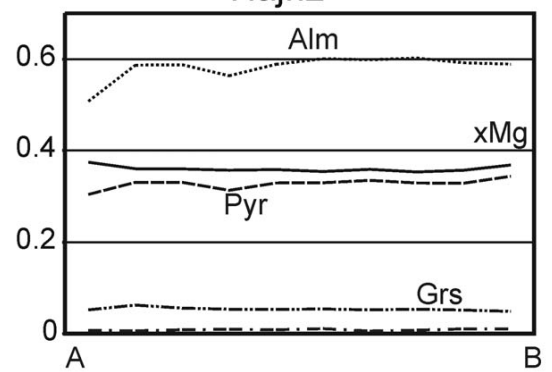

Hajn23

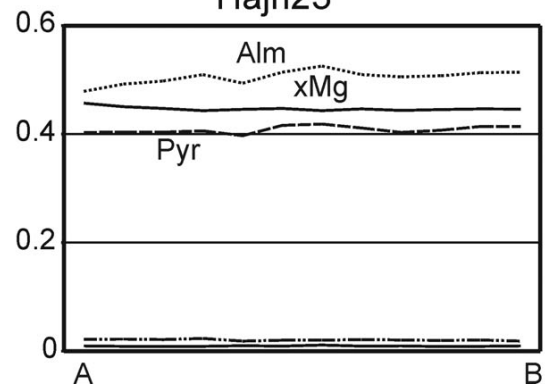

U13-T1-4

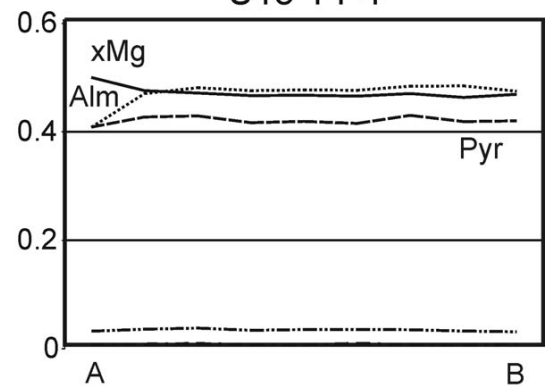

T2-3-T1-39

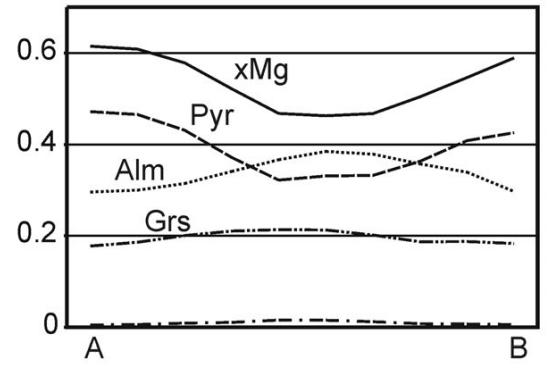

Hajn3

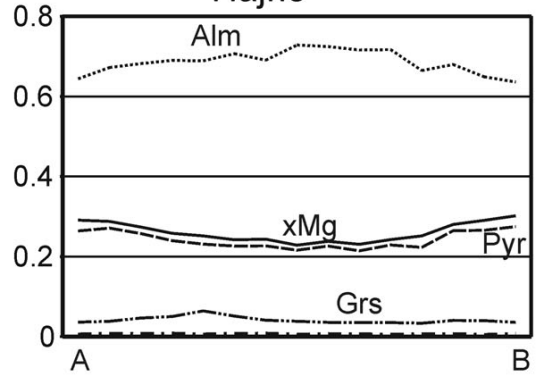

Figure 7. Profiles through garnet grains, zonality discussed in the text. xMg values are calculated as $\mathrm{Mg} /(\mathrm{Mg}+\mathrm{Fe})$. $\mathrm{Location}$ of profiles is shown on Fig. 8 . Sample SPU1, Stará Paka, Vrchlabí Formation, Early Permian (Lower Rotliegende); U13-T1, Úpice, Trutnov Formation, Early Permian (Upper Rotliegende); T2-3-T1, Trutnov - Starý Rokytník, Trutnov Formation; T21-21.5 m, Pekelský vrch, Trutnov Formation; Hajn, Hajnice, Bohdašín Formation, Triassic.

core to the rim. High $\mathrm{xMg}(0.3-0.4$, but also 0.45 and 0.55 ), a grossular component in the range of $2-12 \%$ (up to $20 \%$ ) and a very low spessartine component are characteristic. The homogeneous garnet chemistry, low spessartine and a high $\mathrm{xMg}$ component point to a highgrade metamorphic origin corresponding to granulite facies. The differences in the grossular component content can be explained by variable pressure conditions, including decompression history.
In most samples almandine-pyrope garnets with highgrade metamorphic features dominate. They probably came from southern or north-eastern Moldanubian granulites. The high pyrope garnets may have a possible source area in southern Moldanubian pyroxenite bodies. The dominant southward sources for Permian deposits are in agreement with the palaeoflows. The high-grade metamorphic rocks of the Moldanubian Zone were already exhumed during the Early Permian. Assuming that 

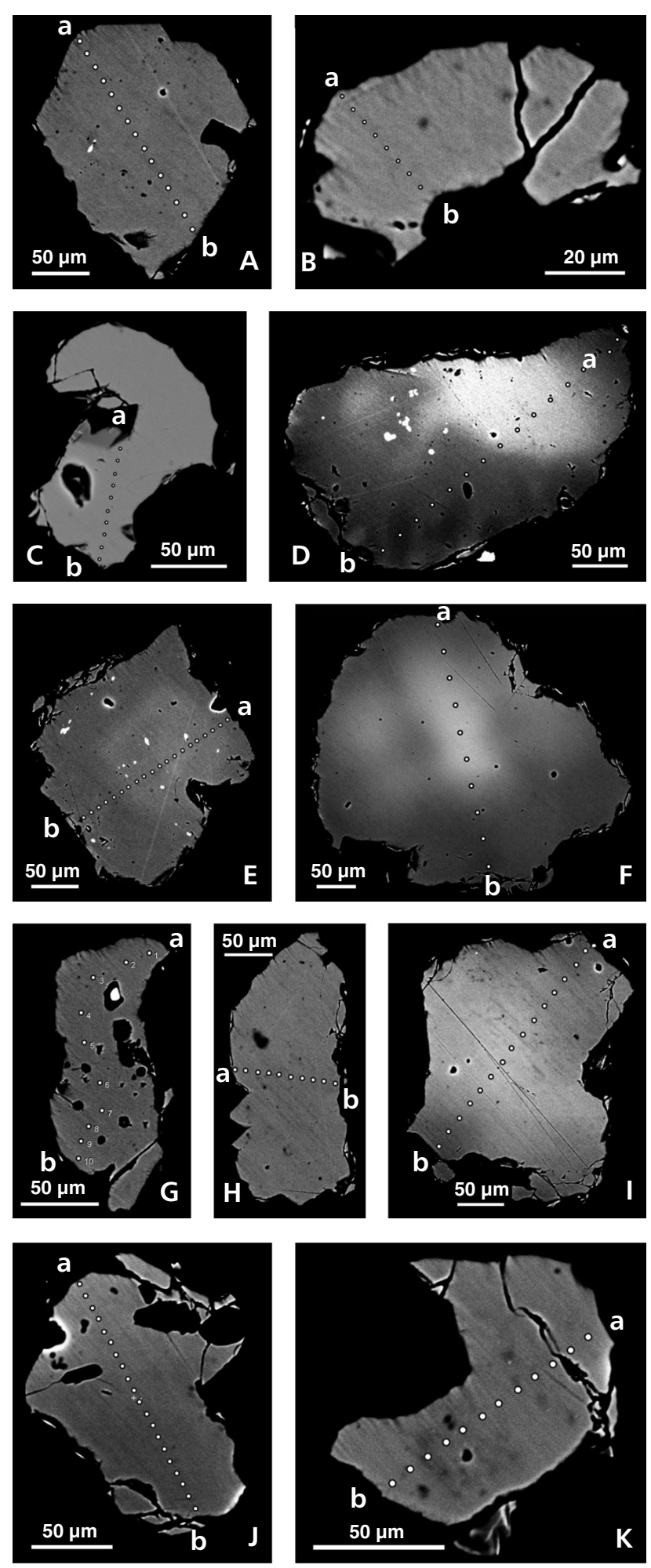

Figure 8. SEM photomicrographs show typical garnet grains with location of profiles (see Fig. 7). Sample SPU1, Stará Paka, Vrchlabí Fm., Early Permian; U13-T1, Úpice, Trutnov Fm., Early Permian; T2-3-T1, Trutnov Starý Rokytník, Trutnov Fm.; T21-21.5 m, Pekelský vrch, Trutnov Fm.; Hajn, Hajnice, Bohdašín Fm., Triassic. • A - SPU1-1. • B - U13-T1-1. - C - U13-T1-4. • D - T2-3-T1-06. E - T2-3-T1-32. • F - T2-3-T1-39. $\bullet$ G - T21-21-1. • H - Hajn2. • I - Hajn3. • J - Hajn6. • K - Hajn 23.
Moldanubian garnets were recycled from Carboniferous, it can be inferred that the Moldanubian Zone was exposed to erosion during the Late Carboniferous, as indicated by the data from Kulm in central Moravia (Dvořák 1973, Hartley \& Otava 2001, Kotková et al. 2007).

Near Vestřev (12 km southwest of Trutnov) an abundant detrital pyrope occurs in Quaternary alluvial gravels, which was exploited for jewellery (̌̌ídkošil et al. 1997). The pyrope composition (0.75 Pyr, 0.13 Alm, 0.04-0.07 Uvar, and 0.01-0.04 Grs) is characteristic of garnet peridotites, but the original source of pyrope near Vestřev is uncertain. No pyrope was found in the nearby Permian sandstones; a possible derivation from Permian volcanic rocks, which could bring pyrope-rich basement rocks, remains to be examined. We can also speculate that pyrope could have been derived from some post-Permian deposits, that are not currently preserved. In the Kolín area, $40 \mathrm{~km}$ south of the studied basin, there are at present relatively abundant local sources of pyrope, that contain characteristically oriented acicular rutile inclusions (Běhal et al. 2000, Vrána 2008). It is nearly certain that the pyrope peridotites near Kolín were not exposed to erosion during the Permian, as it would be difficult to understand the presence of granulite- and pyroxenite-derived garnets in the studied samples interpreted as coming in part from southern Bohemia and the absence of Kolín pyropes. Another problem that remains unresolved is the presence of unusual almandine-spessartine garnets enriched in grossular (T2-3-T1-01). We have not found a possible source rock for such a garnet composition.

\section{Conclusions}

1. Local sources of detrital material are suggested for the Asselian-Guadalupian alluvial fan, nearshore lacustrine and lacustrine fan-delta conglomerate deposits of the north-western and south-eastern basin margin, respectively. Crystalline units of the south-western part of the Krkonoše-Jizera Crystalline Complex and Orlice-Sněžník Crystalline Complex are considered as the most favourable source.

2. The two main possible source areas for the fluvial Asselian deposits of the south-western part of the basin were found. Pebbles of late Devonian-early Carboniferous marine limestones come probably from the central part of the hypothetical Jitrava-Hradec Basin, while the source of sand detrital material could be located in leucogranites and pegmatites of the north-eastern Moldanubian Zone, Přibyslavice area.

3. Guadalupian fluvial deposits reveal a wide range of sources that can be attributed to the recycling of detrital 
material from Cisuralian and Carboniferous deposits. Garnet compositions indicate Moldanubian granulites, garnet clinopyroxenites, leucogranites and pegmatites as possible source.

4. Moldanubian granulites and garnet clinopyroxenites were exposed to erosion in the Early Permian at the latest.

\section{Acknowledgements}

We wish to thank J. Košler and V. Janoušek for sharing their ideas, J. Konopásek for his suggestions, discussions and help with garnet composition interpretations. This research was undertaken as a part of the $\mathrm{PhD}$ thesis of K. Martinek with the support of the Grant Agency of the Czech Academy of Sciences, grant No. KJB3111305 to K. Martínek, the Grant Agency of the Czech Republic, grant No. 205/99/0739 to D. Uličný, and Ministry of Education project No. MSM0021620855. We are grateful to Z. Táborský, F. Veselovský and R. Lojka, of the Czech Geological Survey, for heavy mineral separation and determination, J. Míková for garnet separation and R. Procházka for electron microprobe analyses. Many thanks to R. Withers for the English review. K. Štolfová thanks J. Kalvoda, V. Kachlík and D. Bosence for their suggestions and contribution to the palaeogeographic topics. Special thanks go to K. Holcová for her help with lab processing, her discussions and suggestions concerning micropalaeontology, to V. Kachlík for his information on accessory minerals in crystalline complexes. We also thank P. Čejchan, O. Fatka and P. Budil for discussions on the calcispheres and Palaeozoic of Jítrava and to Peter Haughton for discussion of selected provenance aspects. We gratefully acknowledge the reviewers S. Vrána, J. Schneider, R. Čopjaková, K. Žák, the editor S̆. Manda and anonymous reviewers for improving the manuscript.

\section{References}

BASU, A., Young, S.W., SUTTNER, L.J., JAMES, W.C. \& MACK, G.H. 1975. Re-evaluation of the use of undulatory extinction and polycrystallinity in detrital quartz for provenance interpretation. Journal of Sedimentary Petrology 45, 873-882.

BĚHAL, Z., NOVÁK, F., PAUliš, P. \& PEJŠA, J. 2000. Historická naleziště českého granátu (pyropu) na Kolínsku a jejich mineralogie. Práce muzea v Kolíně, Řada přirodovědná 4, 3-32.

Blecha, M., MARTíNeK, K. \& MihalJEVIČ, M. 1999. Sedimentary and geochemical record of the ancient Kalná Lake, Lower Permian, Krkonoše Piedmont Basin, Czech Republic. Acta Universitatis Carolinae, Geologica 43(4), 657-665.

BREITER, K. 2005. Peraluminické granitoidy sv. moldanubika. Excursion guide, $2^{\text {nd }}$ meeting of the Czech Geological Society, Slavonice, 114-136.

CHLUPÁČ, I. 1964. Nový nález fauny ve slabě metamorfovaném paleozoiku Ještědského pohoří. Časopis pro mineralogii a geologii 9(1), 27-35.

CHLUPÁČ, I. 1997. Poznámky k rozšíření devonu a stavbě meta- morfovaného paleozoika v jižní a střední části Ještědského pohoří. Zprávy o geologických výzkumech v roce 1997, 19-22.

CHLUPÁČ, I. \& ZIKMUNDOVÁ, J. 1976. The Devonian and Lower Carboniferous in the Nepasice bore in East Bohemia. Věstník Ústředního ústavu geologického 51, 269-277.

ČOPJAKOVÁ, R., SUlOVSKÝ, P. \& PATERSON, B.A. 2005. Major and trace elements in pyrope-almandine garnets as sediment provenance indicators of the Lower Carboniferous Culm sediments, Drahany Uplands, Bohemian Massif. Lithos 82(1-2), 51-70.

ČECH, S., HAVlíčEK, V. \& ZIKMUNDOVÁ, J. 1989. The Upper Devonian and Lower Carboniferous in north-eastern Bohemia (based on the boreholes in the Hradec Králové area). Věstník Ústředního ústavu geologického 64, 65-75.

DVOŘÁK, J. 1973. Synsedimentary tectonics of the Palaeozoic of the Drahany Upland (Sudeticum, Moravia, Czechoslovakia). Tectonophysics 17(4), 359-383. DOI 10.1016/0040-1951(73)90126-1

FIALA, J. \& KOPECKÝ, L. 1964. Ke genezi pyropu a jiných granátů v třetihorní sopečné brekcii Velkého vrchu a Malého vrchu u Třtěna. Věstník Ústředního ústavu geologického 39, 267-273. [in Czech]

GALle, A. 1976. Rugose coral Petraiella in the Famennian (Upper Devonian) of Bohemia. Věstník Ústředního ústavu geologického 51, 279.

GLuszeK, A. \& TOMAS, A. 1994. Age of the Nowa Wies Formation (Bardzkie Mts., Middle Sudetes, SW Poland). Annales Societatis Geologorum Poloniae 62, 293-308.

HAQ, B.U. 2007. The Geological Time Table. $6^{\text {th }}$ revised edition. Elsevier, Amsterdam.

HARTLEY, A.J. \& OTAVA, J. 2001. Sediment provenance and dispersal in a deep marine foreland basin. the Lower Carboniferous Culm Basin, Czech Republic. Journal of the Geological Society, London 158, 137-150.

Haughton, P.D.W., TODD, S.P. \& Morton, A.C. 1991. Sedimentary provenance studies, 1-13. In MORTON, A.C., TODD, S.P. \& HAughton, P.D.W. (eds) Developments in Sedimentary Provenance Studies. Geological Society Special Publications 47.

KALVODA, J. 1990. Foraminiferal zonation of the Upper Devonian and Lower Carboniferous in Moravia (Czechoslovakia). Časopis Moravského zemského muzea v Brně, Vědy př́rodní 75, 71-93.

KalvodA, J. 2002. Late Devonian-Early Carboniferous foraminiferal fauna: zonations, evolutionary events, paleobiogeography and tectonic implications. Folia Facultatis scientiarium naturalium Universitatis Masarykianae Brunensis, Geologia 39, 1-213.

Kotková, J., Gerdes, A., PARrish, R.R. \& NovÁK, M. 2007. Clasts of Variscan high-grade rocks within Upper Viséan conglomerates - constraints on exhumation history from petrology and U-Pb chronology. Journal of Metamorphic Geology 25, 781-801. DOI 10.1111/j.1525-1314.2007.00730.x

KUKAL, Z. 1984. Granitoidové plutony byly hlavním zdrojem živců permokarbonských sedimentů. Časopis pro mineralogii a geologii 29, 193-196. 
LOJKA, R. 2003. Sedimentologie aluviálních uloženin a pưvod klastického materiálu trutnovského souvrství ve vnitrosudetské pánvi. 113 pp. Master thesis, Charles University, Prague, Czech Republic.

MACHART, J. \& PADĚRA, K. 1982. Websterit a griquait ze serpentinitu od Bezděčína u Tábora (jižní Čechy). Časopis pro mineralogii a geologii 27(1), 95-102. [in Czech]

MARTÍNEK, K. 1995. Sedimentární facie a interpretace prostředí sedimentace svrchního prosečenského souvrstvi podkrkonošské pánve a geochemie sedimentů kalenského obzoru. $60 \mathrm{pp}$. Master thesis, Charles University, Prague, Czech Republic. [in Czech]

MARTÍNEK, K. 2003. Climatic vs. tectonic controls on the fluvial/alluvial Trutnov Fm., Lower Permian, Bohemian Massif: integrated well-log, outcrop and heavy mineral study $61.22^{\text {nd }}$ IAS Meeting of Sedimentology, Opatija - September 17-19, 2003, Abstracts Book, Zagreb.

MartíneK, K., Blecha, M., DanĚK, V., FrancŮ, J., HlaDíKOVÁ, J., JOHNOVÁ, R. \& ULIČNÝ, D. 2006. Record of palaeoenvironmental changes in a Lower Permian organicrich lacustrine succession. Integrated sedimentological and geochemical study of the Rudník member, Krkonoše Piedmont Basin, Czech Republic. Palaeogeography, Palaeoclimatology, Palaeoecology 230, 85-128. DOI 10.1016/j.palaeo.2005.07.009

MORTON, A.C. 1985. A new approach to provenance studies. electron microprobe analysis of detrital garnets from Middle Jurassic sandstones of the northern North Sea. Sedimentology 32, 553-566. DOI 10.1111/j.1365-3091.1985.tb00470.x

MoRTON, A.C. 1991. Geochemical studies of detrital heavy minerals and their application to provenance research, 31-45. In Morton, A.C., TodD, S.P. \& HAughton, P.D.W. (eds) Developments in Sedimentary Provenance Studies, Geology. Society Special Publications 47.

MORTON, A.C. \& HALLSWORTH, C.R. 1994. Identifying provenance-specific features of detrital heavy mineral assemblages in sandstones. Sedimentary Geology 90, 241-256. DOI 10.1016/0037-0738(94)90041-8

MORTON, A.C. \& HALlSWORTH, C.R. 1999. Processes controlling the composition of heavy mineral assemblages in sandstones. Sedimentary Geology 124, 3-29. DOI 10.1016/S0037-0738(98)00118-3

NOVÁK, F., JANSA, J. \& KAVALÍR, J. 1983. Mineralogický výzkum $v$ hlubokých vrtech v platformnich sedimentech a jejich podloži. Dílči zpráva: Zhodnoceni těžkých minerálů ve vzorcích z vrtů $v$ podkrkonošském permokarbonu. $21 \mathrm{pp}$. Unpublished report, Ústav nerudních surovin Kutná Hora, Kutná Hora.

OWEN, M.R. 1987. Hafnium content of detrital zircons, a new tool for provenance study. Journal of Sedimentary Petrology 57, 824-830.

PEŠEK, J. 1994. Carboniferous of Central \& Western Bohemia (Czech Republic). 60 pp. Czech Geological Survey, Prague.
PEŠEK, J. 2005. Hiatuses between the base of the Pennsylvanian and the base of the Triassic in the Bohemian Massif (Czech Republic). Bulletin of Geosciences 80(1), 67-78.

PETRÁNEK, J. 1978. Byly variské plutony Českého masívu tak rychle obnaženy, že se staly zdrojem materiálu karbonských arkóz? C̆asopis pro mineralogii a geologii 23, 381-387.

PETRÁNeK, J. 1984. Karbonské arkózy, variské granitoidy a subsekventní vulkanismus. Časopis pro mineralogii a geologii 29, 197-210.

POIARKOV, B.V. 1979. Razvitie i rasprostranenie devonskikh foraminifer. 172 pp. Nauka, Moscow.

PROUZA, V. \& TÁSLER, R. 2001. Podkrkonošská pánev, 128-166. In PEŠEK, J., JAROŠ, J., MALÝ, L., MARTíneK, K., PROUZA, V., SPUdIL, J. \& TÁSLER, R. Geologie a ložiska svrchnopaleozoických limnických pánví České republiky. Český geologický ústav, Praha.

ŘíDKOŠIL, T., LANGROVÁ, A. \& KAŠPAR, P. 1997. Gemologické studium pyropu z Podsedic a Vestřevi. Sborník Okresního muzea Českého ráje Turnov, 47-51.

SEIFERT, A. \& VRÁNA, S. 2005. Bohemian garnet. Bulletin of Geosciences 80(2), 113-124.

ŠTOLFOVÁ, K. 2004. Architectural element analysis of fluvial sandstones, Vrchlabi formation, Krkonoše piedmont basin, NE Czech Republic. tectonic and climatic controls. 78 pp. Master thesis, Charles University, Prague, Czech Republic.

TAJČMANOVÁ, L., KonopÁSEK, J. \& SChUlmanN, K. 2006. Thermal evolution of the orogenic lower crust during exhumation within a thickened Moldanubian root of the Variscan belt of Central Europe. Journal of Metamorphic Geology 24(2), 119-134. DOI $10.1111 / j .1525-1314.2006 .00629 . x$

TAPPAN, H. \& LOEBLICH, A.R. Jr. 1988. Foraminiferal evolution, diversification, and extinction. Journal of Paleontology 62(5), 695-714.

TÁSLER, R., HAVlenA, V. \& ProuZA, V. 1981. Nové litostratigrafické členění centrální a západní části podkrkonošské pánve. Věstník Ústředního ústavu geologického 56, 129-143.

TÁSLER, R. \& PROUZA, V. 1985. Podkrkonošská pánev - zhodnocení geologických a uhelně ložiskových poměrů. 60 pp. Unpublished report, Czech Geological Survey, Prague. [in Czech]

UliČNÝ, D., MARTíneK, K. \& GRYGAR, R. 2002. Syndepositional geometry and post-depositional deformation of the Krkonoše Piedmont Basin. A preliminary model. Proceedings of the $7^{\text {th }}$ Meeting of the Czech Tectonic Studies Group, Zelazno, Poland, May 9-12, 2002. Geolines 14, 101-102.

VRÁNA, S. 2008. Mineral inclusions in pyrope from garnet peridotites, Kolín area, central Czech Republic. Journal of Geosciences 53(1), 17-30. DOI 10.3190/jgeosci.018

ZUKALOVÁ, V. 1976. Upper Devonian stromatoporoids, foraminifers and algae in borehole Nepasice (eastern Bohemia). Věstník Ústředního ústavu geologického 51, 281-284. 